\title{
Student Engagement with Online Resources and Its Impact on Learning Outcomes
}

\author{
Lily Wong \\ Victoria University, Melbourne, Australia
}

lily.wong@vu.edu.au

\section{Executive Summary}

There is an increasing demand and expectation for universities to incorporate greater levels of technology into the design and delivery of their curriculum. From an academic perspective, it is of significant interest to determine whether the increased use and availability of online teaching resources have made a positive impact on students' academic performance and whether this is reflected in improved learning outcomes. This paper reports on the findings from a survey of first-year accounting students to assess the level of student engagement with online learning resources. The results indicate that, despite having three new online options readily available via WebCT, students expressed strong support for the traditional face-to-face approaches delivery as the more effective learning options. To determine whether the access to additional online resources had any impact in assisting the students' learning in this subject and potentially affecting their assessment outcomes, a review was conducted to compare the overall pass rates attained. It was found that the period in which the improvement was most significant coincided with the availability of online recordings lectures and tutorials. An investigation of WebCT Course Management Statistical Tools revealed a positive relationship between the level of student engagement with online resources and their overall academic result. Across the key online activities measured, the time spent on each activity was considerably longer for the High Distinction students in comparison to failed students. The analysis of the results has been beneficial in identifying the online learning resources that are most useful in supporting student learning and provide guidance for further enhancement to the design and delivery of e-learning content in this subject.

Keywords: student engagement, online resources, technology, learning outcomes, e-learning

\section{Introduction}

The continual emergence of new technologies has placed academic staff under increasing pressure to react to these substantial changes within a very short and often unrealistic time-frame. As stated by Bates and Poole (2003, p.xiii), one of the major challenges of teaching with technology is that "you cannot possibly keep up with the technology. The paradox of technology enhanced

Material published as part of this publication, either on-line or in print, is copyrighted by the Informing Science Institute. Permission to make digital or paper copy of part or all of these works for personal or classroom use is granted without fee provided that the copies are not made or distributed for profit or commercial advantage AND that copies 1) bear this notice in full and 2) give the full citation on the first page. It is permissible to abstract these works so long as credit is given. To copy in all other cases or to republish or to post on a server or to redistribute to lists requires specific permission and payment of a fee. Contact Publisher@InformingScience.org to request redistribution permission. education is that technology changes very rapidly and human beings change very slowly." This paper is written from the viewpoint of the coordinator of an introductory accounting subject. The students enrolled in this compulsory first-year accounting subject are a very diverse group comprising accounting and non-accounting students from a broad spectrum of business degrees which range from music through to 
marketing. It is important that the curriculum material is developed with an understanding of the differences among these students. Due to the considerable amount of time and effort invested in the design, development and implementation of suitable online resources to support student learning in this subject, validation of its educational value is sought.

\section{Literature Review}

Students in their first year of university have distinct learning needs arising from the social and academic transition they are experiencing. From multiple starting points, all students are on a journey to becoming self-managing and self-directed learners and the first-year curriculum should help get them there (Nelson, Kift, Humphreys \& Harper, 2006). The introduction of e-learning and online resources enables a greater degree of flexibility in providing support for the diverse demands of these students. Ginns and Ellis (2007) acknowledged the increasing pressure for greater integration of new technology into the student learning experience. Wells, de Lange and Fieger (2008) found that the use of technology in educational settings assists in the achievement of learning outcomes. Buzzetto-More (2008) and Sanders \& Morrison-Shetlar (2002) report that student attitudes toward technology are influential in determining the educational benefits of online learning resources and experiences. Research conducted by Perera and Richardson (2010) suggests that the quality of the actual time spent online may be influential on learning outcomes. This provided some support for an earlier study by Davies and Graff (2005) which found that students interacting less frequently with online resources performed less well academically. A more recent study by Williams, Birch, and Hancock (2012) explored the relationship between levels of student engagement with online quizzes and their academic performance. The study found that students who attempted the online quizzes multiple times performed much better than those who attempted a fewer number of times. Osgerby (2013) investigated students' perception of the introduction of a blended learning environment. It was concluded that whilst students appeared to have a positive attitude to the adoption of an organised and well-resourced ICT based learning process, they preferred lectures and step-by-step instruction. Research conducted by Naaj, Nachouki, and Ankit (2012) considered student satisfaction an important factor in measuring the quality of blended learning. Their study proposes that students' satisfaction is influenced by a combination of factors which include the instructor, the technology, class management, interaction, and instruction.

Ginns and Ellis (2007) identify that extensive research into quality student learning in higher education has been conducted by prominent researchers in the field which include Biggs (2003), Entwistle and Ramsden (1983) and Prosser and Trigwell (1999). Outcomes from their research have helped to identify key concepts related to quality learning in higher education and are shown in Figure 1.

Represented in this diagram are the key concepts arising from this research as they relate to the quality of learning achieved by students. This paper will focus on Concept 2, which relates to students' perceptions of the teaching and learning environment. It will investigate students' attitudes towards the traditional face-to-face methods of teaching in comparison to more recent online learning options. The level of student engagement with these online resources and its impact on student learning outcomes will also be discussed. In a recent literature review, Apostolou, Hassell, Rebele, and Watson (2011) highlighted the need for more empirical studies into the effectiveness of using technology in accounting education. The findings of this paper aim to make a positive contribution to this area of research. 


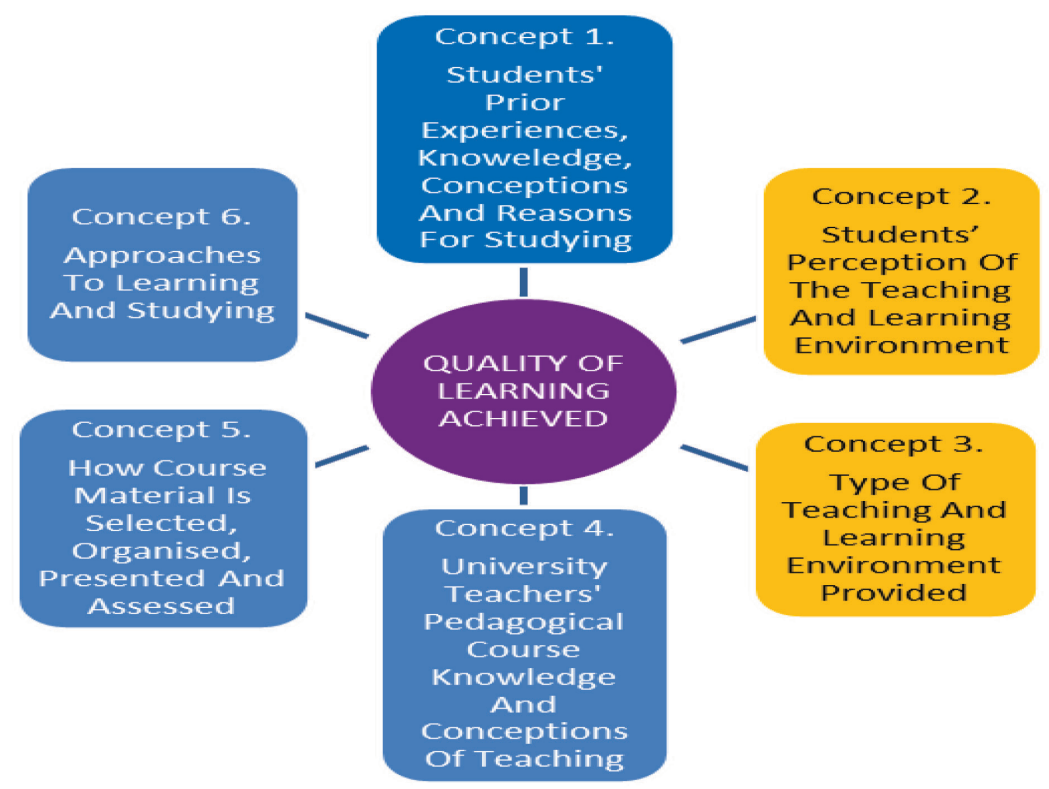

Figure 1 - Concepts Related To The Quality Of Learning At University Adapted from Entwistle, McCune, \& Hounsell (2002, p.6)

\section{Methodology}

To assess the level of student engagement with online learning resources and the impact of these resources on learning outcomes, a quantitative approach was adopted for this research. The primary source of statistical data used in this paper has been extracted from a survey specifically designed to identify students' attitudes towards e-learning in the first-year accounting subject offered by Victoria University.

\section{Background on the Study University}

Victoria University, located in Melbourne, Australia, has one of the most culturally and linguistically diverse student populations within the state of Victoria. There are a large number of firstgeneration university entrants, the first in their family to attend university. Also included amongst the student population are those from a low socio-economic background. It is therefore important to provide additional support for their specific learning needs. One of Victoria University's key strategies is to enhance the quality of the learning experience by incorporating a greater use of technology in the teaching and learning process; this trend toward blended learning is emerging as perhaps the most prominent method of delivery in higher education (Bonk \& Graham, 2006). Since 2006 there has been an increasing amount of online resources used in Victoria University's introductory accounting subject. A review of the overall pass rate before and after these technological enhancements will be used to determine its impact on learning outcomes.

WebCT, an online learning platform provided by the Blackboard Learning System, was introduced into the first-year accounting subject in Semester 1/2006. Students were provided with a basic level of online teaching resources which included lecture notes and exam solutions. In each of the following semesters, additional resources were made available. These now include instructional videos, online assessment, access to recorded lectures and tutorials, as well as participation in an online tutorial. There is also greater use of communication tools, in particular online chat and discussion boards for students to communicate with each other and their lecturers via WebCT. Students' perceptions of the effectiveness of the online resources and the level of engagement with them will also be discussed. 


\section{The Survey}

The survey instrument comprised three sections. The first section provided a profile of the socioeconomic and educational background of the sample. The second section rated the students' study preferences toward the traditional face-to-face lectures and tutorials, as well as new online teaching options. Each of the options were listed and students were asked to rate their effectiveness of each in assisting their learning in this subject by using a 4 point rating scale. The quality and usefulness of the key features on the subject's website was also evaluated in the same manner. This section also included three open-ended questions seeking students' recommendations on what additional online resources should be incorporated into this subject's website to further help with their learning. The third section provided an overview of the students' learning experience in this subject. Students were asked to respond to a series of statements relating to quality of teaching, assessment, workload and their attitudes toward study by using a 5 point Likert scale.

The length of the survey was limited to three pages and required approximately 10 to 15 minutes to complete to encourage greater student participation. Informal feedback sourced from student emails received during the relevant semesters under review was considered in the analysis of student responses.

The survey was distributed to students in the last lecture at the end of each semester and student participation was voluntary. Survey data was collated and entered into IBM SPSS Statistics 20 software for statistical analysis. Additional sources of information were retrieved from the university's student database, the Victoria University Student Information System (VUSIS), and analytical tools were available on the WebCT course management system for statistical tracking of the usage of the online resources. Academic performance measures and learning outcomes were calculated from comprehensive records kept on Microsoft Excel spreadsheets detailing each component student assessment.

This is a longitudinal study conducted over four consecutive semesters commencing from Semester $1 / 2010$ through to Semester $2 / 2011$. The aim of this research was to identify students' attitudes toward traditional and online methods of delivery and to determine whether the level of student engagement with online teaching resources had made a positive impact on their academic performance in this first-year accounting subject.

\section{Demographic Profile}

Table 1 provides a demographic profile of the students surveyed over the four semesters under review from Semester 1/2010 through to Semester 2/2011.

\section{Sample Size}

The largest sample size of 172 students was attained in first semester of the survey period but this decreased steadily with only 87 students responding to the survey in the fourth semester. This is reflective of the lower number of students enrolled for this period and lower attendance in lectures. It is possible that this trend may be related to the introduction of recorded lectures and tutorials becoming available online from Semester 1/2010 onwards.

\section{Gender}

In semesters $1 / 2010$ and $1 / 2011$ males students represented a slightly higher proportion than female students. This reversed in Semester 2/2010 and 2/2011 with female students more dominant in the sample. 
Table 1 - Demographic Profile of Survey Participants

\begin{tabular}{|c|c|c|c|c|}
\hline & $\begin{array}{c}\text { Sem. } \\
1 / 2010\end{array}$ & $\begin{array}{c}\text { Sem. } \\
2 / 2010\end{array}$ & $\begin{array}{c}\text { Sem. } \\
1 / 2011\end{array}$ & $\begin{aligned} \text { Sem. } \\
2 / 2011\end{aligned}$ \\
\hline $\begin{array}{l}\text { Number of Students Enrolled } \\
\text { at End of Semester }\end{array}$ & 561 & 495 & 468 & 424 \\
\hline Sample Size & 172 & 112 & 143 & 87 \\
\hline Gender & $\%$ & $\%$ & $\%$ & $\%$ \\
\hline Male & 56 & 37 & 53 & 47 \\
\hline Female & 44 & 63 & 47 & 53 \\
\hline Mode of Study & $\%$ & $\%$ & $\%$ & $\%$ \\
\hline Full-Time & 88 & 88 & 87 & 87 \\
\hline Part-Time & 12 & 12 & 13 & 13 \\
\hline Which year of study are you in? & $\%$ & $\%$ & $\%$ & $\%$ \\
\hline $1 \mathrm{st}$ & 64 & 67 & 67 & 70 \\
\hline other & 36 & 33 & 33 & 30 \\
\hline Are your major studies in Accounting? & $\%$ & $\%$ & $\%$ & $\%$ \\
\hline Yes & 35 & 8 & 19 & 15 \\
\hline No & 65 & 92 & 81 & 85 \\
\hline Work and Study & $\%$ & $\%$ & $\%$ & $\%$ \\
\hline Not working & 27 & 25 & 31 & 31 \\
\hline $1-10$ hours of work & 16 & 9 & 11 & 14 \\
\hline $11-20$ hours of work & 30 & 44 & 31 & 30 \\
\hline $21-30$ hours of work & 15 & 12 & 16 & 14 \\
\hline Greater than 30 hours & 12 & 10 & 11 & 11 \\
\hline Age & $\%$ & $\%$ & $\%$ & $\%$ \\
\hline Less than 20 years & 44 & 36 & 39 & 36 \\
\hline $20-29$ years & 47 & 58 & 49 & 52 \\
\hline 30 years or older & 9 & 6 & 12 & 12 \\
\hline Studied Accounting Previously & $\%$ & $\%$ & $\%$ & $\%$ \\
\hline Yes & 39 & 22 & 37 & 23 \\
\hline No & 61 & 78 & 63 & 77 \\
\hline Work Experience in Accounting & $\%$ & $\%$ & $\%$ & $\%$ \\
\hline Yes & 13 & 5 & 10 & 5 \\
\hline No & 87 & 95 & 90 & 95 \\
\hline How many lectures did you attend? & $\%$ & $\%$ & $\%$ & $\%$ \\
\hline None & 1 & 2 & 1 & 1 \\
\hline some & 49 & 50 & 60 & 58 \\
\hline All 24 lectures & 50 & 28 & 39 & 41 \\
\hline How many tutorials did you attend? & $\%$ & $\%$ & $\%$ & $\%$ \\
\hline None & 0 & 0 & 0 & 0 \\
\hline some & 41 & 52 & 48 & 52 \\
\hline All 12 tutorials & 59 & 48 & 52 & 48 \\
\hline
\end{tabular}

\section{Mode of Study}

The vast majority of students $(87 \%$ to $88 \%)$ were studying in full-time mode. These figures remained consistent over the 4 semesters under review. 


\section{Year of Study / Previous Accounting Studies / Work Experience}

For a large proportion of these students, this subject is undertaken as their first semester in the first year of study at this university. In Semester 1/2010 this accounted for $67 \%$ of survey participants; by Semester 2/2011 this had increased to $70 \%$, the highest proportion of first year students over the survey period. A significant majority of students ranging from $61 \%$ to $78 \%$ have no previous accounting studies. The percentage of students with work experience in accounting was very low representing from $5 \%$ to $13 \%$ of this sample. These results may be due to the low proportion of accounting majors in this sample.

\section{Major Area of Study}

A minority of students enrolled in this compulsory accounting subject are accounting majors. In Semester 1/2010, this amounted to $35 \%$ and in Semester 2/2010 this was at its lowest with only $8 \%$ of students identified as accounting majors. This is one of the major challenges in engaging these students in the learning of accounting as it is an area of study in which there is little or no interest. The survey results show a larger percentage of students from a non-accounting background in the second semester of each year as accounting majors generally complete this subject in the first semester to be eligible for sequential accounting subjects.

\section{Work and Study}

A significant majority of students are working and studying. Of this group of students, the percentage of students that were working between 11 to 30 hours of work each week ranged from $44 \%$ to $56 \%$. It was also found that up to $12 \%$ of these students worked more than 30 hours per week. This is perhaps reflective of the generally low to medium socio-economic status of the university's student demographic in which students are required to work long hours to cover their educational and living expenses. More flexible learning options may be beneficial to this group to enable them to continue with their studies despite substantial work commitments. The proportion of students that are not working and able to more fully focus on their studies ranged from $25 \%$ to $31 \%$.

\section{Age}

The dominant groups are those students less than 20 and those between 20 to 29 years old. These two younger groups combined represent approximately $88 \%$ to $94 \%$ of surveyed students in comparison to mature students aged 30 years or older who account for only $6 \%$ to $12 \%$ of this group.

\section{Lectures and Tutorials Attended}

The percentage of students who attended all lectures was quite low with an attendance rate of $50 \%$ recorded in Semester 1/2010. This declined over the three consecutive semesters, with the lowest attendance rate of $28 \%$ recorded in Semester $2 / 2010$. It is also noted that $1 \%$ to $2 \%$ of students did not attend any lectures during the semester.

A similar trend is seen in the percentage of students attending all tutorials with a slightly higher attendance rate of 59\% recorded in Semester 1/2010. This also dropped in the following semesters with the lowest attendance rate of $48 \%$ recorded in Semester 2/2010 and Semester 2/2011. In contrast to lecture attendance, there were no students in this survey who did not attend any tutorials. This is probably due to students having to complete a mid-semester test. As this is a compulsory assessment for the subject, each student attended at least one tutorial. 


\section{Results}

In Semester 1/2010, students were introduced to three new online learning options to complement traditional face-to-face lectures and tutorials. These included the viewing of recorded lectures via Lectopia, an automated lecture recording and web publishing tool. Students were also given the opportunity to enroll and participate in online tutorials via Elluminate Live which is an online collaborative session. To join the online tutorial they were required to login to the Elluminate Live website each week at a regular designated time. These sessions were conducted by the subject coordinator. The transfer of knowledge and review of tutorial content was facilitated through shared files or a shared whiteboard which students could also take control of screen for direct input. Interaction between the online tutor and students was enabled through an onscreen dialogue sidebar or speaking directly via microphone or headset. The Elluminate Live tutorials were recorded and access to all these additional online resources was through WebCT.

A screen capture of an Elluminate Live session highlighting these particular features is provided in Figure 2.

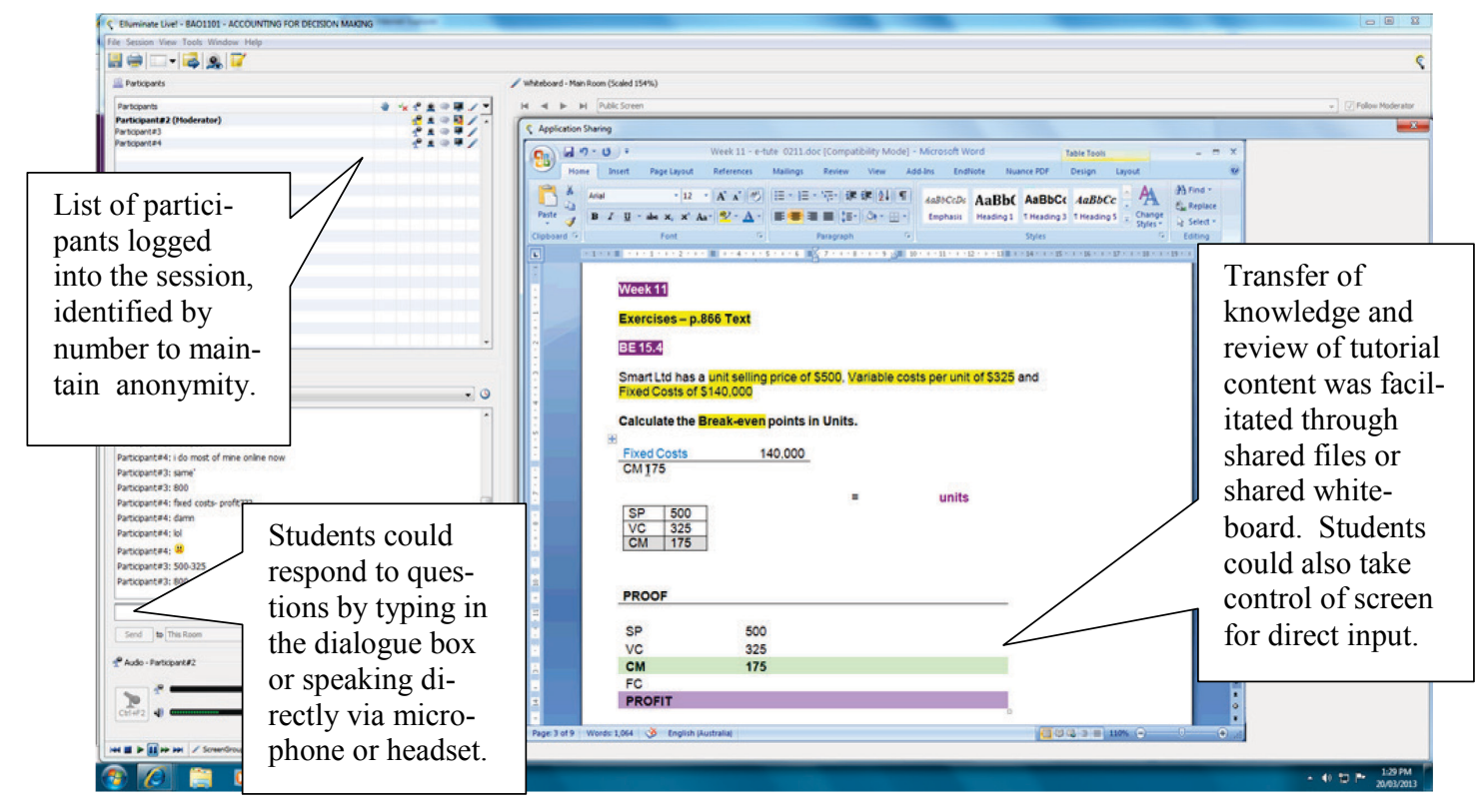

Figure 2 - Screen Capture of Elluminate Live Session

\section{Students' Perceptions of Effectiveness of Learning Options}

To gauge how students perceived the effectiveness of each of these options, a 4 point rating scale was used with $1=$ not at all effective, $2=$ some effect, $3=$ effective and $4=$ very effective.

The mean scores calculated for each of these options are shown in Table 2. 
Table 2 - How Effective Was Each Of These Options In Assisting Your Learning In This Subject?

\begin{tabular}{|l|c|c|c|c|}
\hline & $\begin{array}{c}\text { Semester } \\
1 / 2010\end{array}$ & $\begin{array}{c}\text { Semester } \\
2 / 2010\end{array}$ & $\begin{array}{c}\text { Semester } \\
1 / 2011\end{array}$ & $\begin{array}{c}\text { Semester } \\
2 / 2011\end{array}$ \\
\hline Lectures - face-to-face & 3.42 & 3.19 & 3.39 & 3.64 \\
\hline Lectopia - recorded lectures & 2.75 & 2.84 & 2.92 & 3.05 \\
\hline Tutorials - face-to-face & 3.33 & 3.07 & 3.20 & 3.33 \\
\hline $\begin{array}{l}\text { Elluminate } \\
\text { - viewing recorded tutorials }\end{array}$ & 2.51 & 2.25 & 2.63 & 2.54 \\
\hline $\begin{array}{l}\text { Elluminate Live } \\
\text { - participating in online tutorials }\end{array}$ & 2.46 & 2.51 & 2.68 & 2.34 \\
\hline
\end{tabular}

A graphical representation of the mean scores for each learning option is shown in Figure 3.

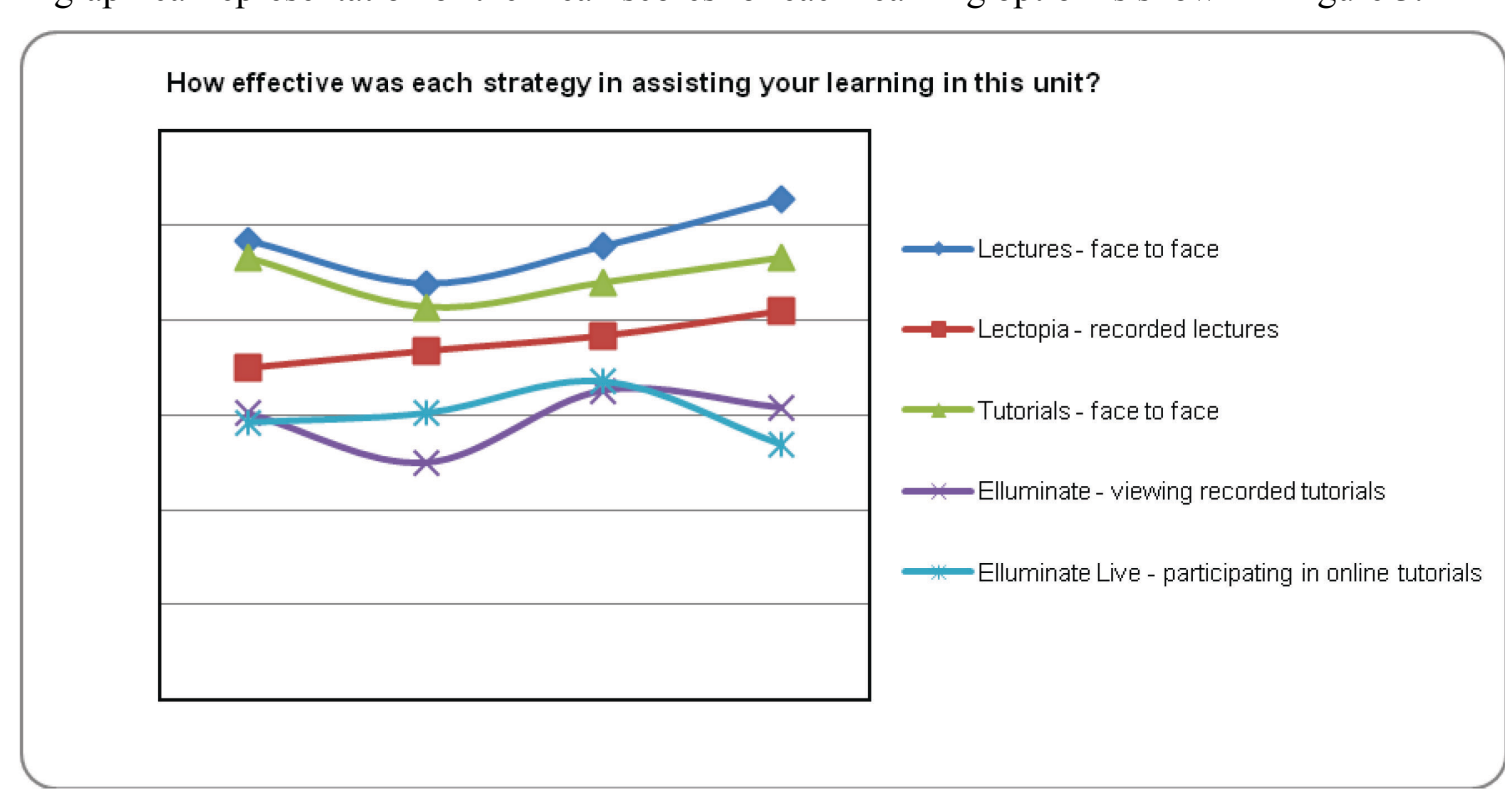

Figure 3 - Effectiveness of Each Option in Assisting Learning

Despite having three new online options readily available via WebCT (the viewing of recorded lectures, the viewing of recorded tutorials, and participation in an online tutorial), there was strong support for traditional face-to-face delivery. There was an initial decline in the mean scores in Semester 2/2010 for face-to-face lectures and tutorials, but from this point onwards, an upward trend continued for both approaches through to Semester 2/2011. The results indicated that the students perceived face-to-face lectures as the most effective option in assisting their learning in this subject with a mean of 3.64 which peaked in Semester 2/2011. A similar trend was evident for face-to-face tutorials with a slightly lower mean of 3.33 for the same period.

Of the online options, the viewing of recorded lectures rated was rated the most highly. Even though it was the only option in which the mean score showed a continual increase from 2.75 in Semester 1/2010 to 3.05 in Semester 2/2011, it rated well below the face-to-face options.

These results appear to be consistent with research by Halabi, Tuovinen, and Farley (2005) on student attitudes toward tele-teaching and traditional face-to-face contact. Preference for face-toface teaching was reported in this study and more recently in Osgerby (2013) who concluded that whilst students appeared to have a positive attitude to the adoption of organised and well- 
resourced ICT-based learning options, they still preferred traditional lectures and step-by-step instruction. Over the four semesters, the viewing of recorded tutorials and participation in online tutorials rated the lowest of all the learning options. With mean scores ranging from 2.25 to 2.63 and 2.34 to 2.68 respectively, students perceived these two options to have only some effect in assisting their learning. These low scores are perhaps indicative of their preference for active involvement through student interaction rather than passive viewing of online recordings. Bates and Poole (2003, p. 98) state that "most theories of learning suggest that for learning to be efficient, it needs to be active ... the learner must respond in some way to the learning material." Students learn better when they are actively engaged with their learning rather than being passive receptacles of information.

Despite the constant promotion of the online tutorial as a new and flexible learning option over the four semester period, the enrolments remained low with the numbers ranging between 5 to 10 students per tutorial. The number of participants would fluctuate from week to week so the actual number of students online was at times below this stated range. This may be perceived to be a benefit to those who did participate as it provided a more personalised learning experience compared to a traditional classroom tutorial of 25 students. As an instructor, one is able to better gauge the level of understanding of each individual student through the one-to-one interaction online in which student anonymity is maintained. This seemed to encourage more open discussion amongst participants and provide a more active and collaborative learning experience, particularly for those students who feel uncomfortable asking questions in a large tutorial group. It was interesting to note that in Semester 2/2011, the mean score for the participation in the online tutorials was at its lowest at 2.34, whilst the viewing of the recorded tutorials rated slightly higher at 2.54 .

The overall decline in the mean scores for face-to-face lectures, face-to-face tutorials and viewing online tutorials for Semester 2/2010 may be attributed to the student profile for this period. With reference to demographic details in Table 1, it can be seen that $92 \%$ of this particular group are non-accounting majors of which $78 \%$ have no prior studies in accounting, the largest proportion in these categories across the 4 semesters surveyed. It also shows that $44 \%$ of these students were working between 11 to 20 hours, which is substantially higher than the $30 \%$ and $31 \%$ recorded in the other semesters from $1 / 2010$ to $2 / 2011$. This may have contributed to the lower attendance rates for Semester $2 / 2010$ which show that only $28 \%$ of these students attended all lectures and $48 \%$ attended all tutorials, the lowest over the four semesters reviewed. This may have also influenced the increase in the effectiveness of the Lectopia recorded lectures and Elluminate recorded tutorials to make up for missed classes during this semester.

Students' support for participation in online tutorials as an effective strategy to enhance their learning rose slightly from Semester $1 / 2010$ to Semester $1 / 2011$. The mean score increased marginally over the three consecutive semesters from 2.46 to 2.68 , but dipped to its lowest point of 2.34 in Semester 2/2011. Despite numerous attempts by the subject coordinator to raise student awareness of these online tutorials during this semester, this did not seem to improve the low number of enrolments nor strengthen their perception that this was a viable alternative to face-toface learning.

\section{Student Feedback on Online Learning}

As this is the largest accounting subject offered at the university, the teaching is shared between several teaching staff. Consequently, students may be exposed to a range of learning experiences due to differing interpretations of subject content, as well as divergent teaching styles. This was often confusing for students. In an attempt to provide consistency, the unit coordinator's online recordings of lectures and tutorials were posted on WebCT. The popularity for online recordings 
is reported in Osgerby (2013), in which several students specify that they would have liked recordings of lectures to be available, only if the lecturers were proficient in their subjects.

Despite the lowest mean score of 2.34 recorded in Semester 2/2011, the informal feedback from students participating in these online tutorials was very positive as a flexible learning option which enhanced their learning. Samples of feedback are provided below.

Feedback from an online participant Sem. 2/2011 - extract from email 27/10/2011

"Just wanted to say again how fantastic it has been being a student of BAO1101 this semester. I personally have found the online element and your teaching style extremely advantageous to my learning and thank you greatly for being such an inspirational teacher. I encourage you to keep trying to offer this subject to other students as it had been extremely helpful to me as a travelling student. Though class numbers and the obvious difficulty of distance affects your belief in this (online) subject $i$ encourage you to keep doing what you're doing and only hope that other students can appreciate as much as $i$ do what you have done for me this semester".

Feedback from a viewer of online recordings Sem.2/2011- extract from email 6/09/2011 First of all thank you for the opportunity to access both the lecture recordings and online tutorial recordings, I have found them of great assistance and your teaching style is easy for me to follow. Although I attend both my tutorial and lecture I find I am able to use the recordings for better understanding of the subject".

Feedback from a viewer of online lectures Semester 2/2010- extract from email 27/08/2010 "I am just writing to say thank you and to mention how much I enjoy listening to your lectures. I have been away due to a surgery I recently had so I have been following along with the subject through the recorded lectures and I find your teaching style not only to be very easy to understand and follow, but you make the subject actually enjoyable to study. I have found it very difficult to find lecturers who not only make the subject easier to understand, but have the enthusiasm to want to make their students get the most out of the subject. You definitely have a great passion for this subject as well as a passion for teaching, which is rare. Thank you again and I look forward to learning more from you throughout the semester".

\section{Impact of Online Lectures and Tutorials on Learning Outcomes}

The availability of online recordings of lectures and tutorials and their potential impact on learning outcomes is presented in Table 3 below.

Table 3 - Overall Pass Rate

\begin{tabular}{|l|c|c|c|c|c|c|c|c|c|}
\cline { 2 - 10 } \multicolumn{1}{c|}{} & $\begin{array}{c}\text { Prior } \\
\text { to } \\
\text { WebCT }\end{array}$ & \multicolumn{4}{c|}{$\begin{array}{c}\text { With } \\
\text { WebCT }\end{array}$} & \multicolumn{3}{c|}{$\begin{array}{c}\text { WebCT Access To Recorded } \\
\text { Lectures And Tutorials }\end{array}$} \\
\cline { 2 - 10 } & $\mathbf{2 0 0 5}$ & $\mathbf{2 0 0 6}$ & $\mathbf{2 0 0 7}$ & $\mathbf{2 0 0 8}$ & $\mathbf{2 0 0 9}$ & $\begin{array}{c}\text { Sem. } \\
\mathbf{1 / 2 0 1 0}\end{array}$ & $\begin{array}{c}\text { Sem. } \\
\mathbf{2 / 2 0 1 0}\end{array}$ & $\begin{array}{c}\text { Sem. } \\
\mathbf{1 / 2 0 1 1}\end{array}$ & $\begin{array}{c}\text { Sem. } \\
\mathbf{2 / 2 0 1 1}\end{array}$ \\
\hline $\begin{array}{l}\text { Sample } \\
\text { Size* }\end{array}$ & 992 & 1,090 & 1,357 & 1,134 & 1,289 & 561 & 495 & 468 & 424 \\
\hline $\begin{array}{l}\text { Pass } \\
\text { Rate }\end{array}$ & $73 \%$ & $68 \%$ & $77 \%$ & $71 \%$ & $70 \%$ & $80 \%$ & $76 \%$ & $82 \%$ & $72 \%$ \\
\hline
\end{tabular}

* Sample Size is based on number of students completing final exam

Table 3 shows that the improvement was most significant from 2009 to Semester 1/2010 where the overall pass rate increased from $70 \%$ to $80 \%$ which seems to coincide with the availability of 
recorded lectures and tutorials via WebCT. It is also acknowledged that there may be other contributing factors influencing these results, some of these are summarised in Table 4 below.

Table 4 - Possible Factors Impacting on Pass Rate

\begin{tabular}{|l|c|c|c|c|}
\hline & $\begin{array}{c}\text { Semester } \\
\mathbf{1 / 2 0 1 0}\end{array}$ & $\begin{array}{c}\text { Semester } \\
\mathbf{2 / 2 0 1 0}\end{array}$ & $\begin{array}{c}\text { Semester } \\
\mathbf{1 / 2 0 1 1}\end{array}$ & $\begin{array}{c}\text { Semester } \\
\mathbf{2 / 2 0 1 1}\end{array}$ \\
\hline Pass Rate & $\mathbf{\%}$ & $\mathbf{\%}$ & $\mathbf{\%}$ & $\mathbf{\%}$ \\
\hline Non-accounting majors & 80 & 76 & 82 & 72 \\
\hline No previous accounting studies & 65 & 92 & 81 & 85 \\
\hline Working from 11 to 30 hours per week & 61 & 78 & 63 & 77 \\
\hline Attended all lectures & 50 & 56 & 47 & 44 \\
\hline Attended all tutorials & 59 & 28 & 39 & 41 \\
\hline
\end{tabular}

\section{Proportion of Non-Accounting Majors}

The decrease in the pass rate from to Semester $1 / 2010$ to Semester $2 / 2010$ from $80 \%$ to $76 \%$ may be due to the significantly larger proportion of non-accounting majors, $65 \%$ compared to $92 \%$ in the latter semester, In Semester 1/2011, the highest pass rate over the four semester survey period of $82 \%$ was achieved with $81 \%$ of non-accounting majors. By Semester 2/2011 the pass rate had dropped substantially from $82 \%$ to $72 \%$, marginally below the $73 \%$ pass rate recorded prior to the introduction of WebCT. If the Semester 1 results for each semester are compared in isolation, the pass rate has improved from $80 \%$ to $82 \%$. This result may be due to the larger proportion of accounting majors enrolled in the first semester of each year. A similar comparison with the Semester 2 results shows a decline in the pass rate from $76 \%$ to $72 \%$ possibly due to the larger proportion of non-accounting majors enrolled during this period.

\section{Previous Accounting Studies}

The high proportion of students with no previous accounting studies was similar for each of the first and second semesters, around $61 \%$ and $77 \%$ respectively. Coupled with substantially higher proportion of non-accounting majors for the same period, these two factors appear to be the most influential in the overall pass rate.

\section{Hours Worked Per Week}

The percentage of students that were working between 11 and 30 hours ranged from $45 \%$ to $56 \%$ over the four semesters reviewed. This appears to be a considerable workload undertaken given that approximately $88 \%$ of the students surveyed over this period were full-time students. This may also have a direct effect on level of attendance in tutorials and lectures during the semester. These students may have found the online recordings a flexible learning option enabling them to continue with their studies and managing their work commitments.

\section{Attendance}

There was a downward trend in the level of attendance for all lectures, dropping from $50 \%$ in Semester $1 / 2010$ to its lowest point of $28 \%$ in the following semester. There was a significant increase in Semester 1/2011 and 2/2011, with lecture attendance rates up to 39\% and 41\% respectively. The level of attendance for all tutorial was at its highest in Semester 1/2010 at 59\% but decreased to its lowest level of $48 \%$ in both Semester 2/2010 and 2/2011. The attendance in tutorials is higher for the same period as students have internal assessments which are conducted in 
the tutorial and require their attendance. Despite the low attendance rates which are mostly below $50 \%$ for lectures and tutorials, there is a substantial improvement in the overall pass rate which peaked at $82 \%$ in Semester 1/2011. This is considerably higher than the $73 \%$ pass rate attained prior to WebCT. It is interesting to note that this was achieved when the proportion of students attending all lectures had declined from $50 \%$ to $39 \%$ and the proportion of students attending all tutorials was down from $59 \%$ to $52 \%$.

Whilst the increased use of web-based technologies such as Lectopia and Elluminate may have some impact on the low attendance rates, Taplin, Low, and Brown (2011) acknowledge research by Phillips, Gosper, McNeill, Woo, Preston, and Green (2007) and von Konsky, Ivins, and Gribble (2009) who argue that other factors contribute to falling attendance rates. These include the changing lifestyles of students as well as their changed perceptions of the learning experience provided.

As can be seen from the data in Table 4, there is the possible interplay of different factors impacting on the overall pass rate. It suggests that where students are working longer hours, where there are a large proportion of non-accounting students with no previous accounting studies and low attendance rates, the overall pass rate may be adversely affected.

Table 5 - Level of Engagement and Learning Outcomes for Semester 2/2011

\begin{tabular}{|c|c|c|c|c|c|c|}
\hline & $\begin{array}{c}\text { Number } \\
\text { of } \\
\text { Sessions }\end{array}$ & $\begin{array}{l}\text { Hours } \\
\text { Spent }\end{array}$ & $\begin{array}{c}\text { Online } \\
\text { Assessments } \\
\text { Attempted } \\
\\
\text { Maximum } \\
=22 \text { times }\end{array}$ & $\begin{array}{c}\text { Average } \\
\text { Time } \\
\text { On } \\
\text { Assess- } \\
\text { ments } \\
\text { Maximum } \\
=5.5 \text { hours }\end{array}$ & $\begin{array}{c}\text { Files } \\
\text { Viewed }\end{array}$ & $\begin{array}{l}\text { Discussion } \\
\text { Board } \\
\\
\text { Messages } \\
\text { Read }\end{array}$ \\
\hline \multicolumn{7}{|l|}{ HD (80-100) } \\
\hline Frequency / Hours & 4,352 & 1,106 & 1,002 & 190 & 5,056 & 209 \\
\hline No. of Students & 52 & 52 & 52 & 52 & 52 & 52 \\
\hline Average* & 84 & 21 & 19 & 4 & 97 & 4 \\
\hline \multicolumn{7}{|l|}{ N2 (0-39) } \\
\hline Frequency / Hours & 3,492 & 790 & 1,000 & 170 & 6,276 & 152 \\
\hline No. of Students & 134 & 134 & 134 & 134 & 134 & 134 \\
\hline Average* & 26 & 6 & 7 & 1 & 47 & 1 \\
\hline
\end{tabular}

Details accessed from WebCT Course Management Statistical Tools

*Average figures have been rounded up to nearest whole number

Table 5 shows the level of student engagement with some of the key online resources on WebCT which may assist their learning in this subject. It provides a breakdown of the number of sessions each student logged into, the average time spent on these sessions, the number of online assessments attempted, as well as the average time spent on the online assessments. The frequency of files viewed and the students' participation in discussion board activities is also included to help determine whether the level of interaction with the subject website and learning materials was an influential factor in their overall academic performance.

Two distinct groups of students were compared. The first group being the 'High Distinction' students attaining a final mark between 80 and 100, the latter being the 'N2' students, those who clearly failed the subject with a final mark between 0 and 39 . 


\section{Sessions Logged}

Students are required to logon regularly to the subject website for updates, online assessment, as well as access to important learning materials which include recordings of lectures and tutorials, assignment details, sample tests, past exams, and solutions. On average, High Distinction students logged into 84 sessions and spent approximately 21 hours engaging with the online resources, whereas the failed N2 students logged into 26 sessions and spent approximately 6 hours on WebCT during the semester. This seems to be in contrast with research conducted by Perera and Richardson (2010) which found that the number of online sessions a student logged into was not significantly related to students' academic performance. However, their findings did suggest that the actual time spent online provided some support for an earlier study by Davies and Graff (2005) which found that students interacting less frequently performed less well academically. However, it could be argued that there is likely to be a correlation between the number of hours a student spends online with the number of hours that they spend studying offline.

\section{Online Assessments Attempted}

The online assessments comprised eleven tests which were released on a weekly basis to reinforce the students' understanding of the weekly lecture and tutorial content. Students were allowed two attempts for each of these eleven tests, therefore the maximum number of 22 attempts was allowed. The highest score from the two attempts for each of the weekly tests counted toward their final mark. These tests represented $10 \%$ of the total assessment in the subject.

The tests comprised theory and practical elements which required some calculations. After completion of each test, students were given immediate feedback on their score and incorrect answers were identified. On average, the High Distinction students attempted the weekly tests 19 times, in comparison to the N2 students who attempted seven times out of the maximum 22 times allowed. These results appear consistent with the findings of Williams et al. (2012) which indicate that students who attempted the online quizzes multiple times performed much better than those who attempted each quiz only once or not at all. Similar results were reported in Osgerby (2013) whereby students regarded online quizzes as very popular where instant feedback is provided. Students also stated that they often repeated the tests as it was helpful to enhancing their background information and building up their confidence.

It was also found that the High Distinction students took a longer time to complete their online assessment, spending approximately four hours out of the 5.5 hours allowed, which is substantially higher than the one hour taken by the N2 students. This may be due to the additional time by the High Distinction group to calculate the answers which could possibly demonstrate a deeper understanding of the technical content than the N2. The lesser time taken by this group may be due to students guessing the answers rather than working through each of the possible options to find the correct answer. Perera and Richardson (2010) propose that it is the quality of time spent within the online environment that has a relationship with students' academic outcomes.

\section{Files Viewed}

These files comprise essential learning materials which include lecture notes, tutorial content, assignment details, marking schemes as well as links to websites that are relevant to the subject content and assessment. A similar pattern is evident with the High Distinction students viewing 97 files in contrast to the 47 viewed by the N2 students during the semester. As these files were integral to students' learning, assessment and exam preparation, these results show a potential link between the number of files viewed and improved results. This appears to be consistent with the findings reported by Perera and Richardson (2010). 


\section{Discussion Board}

The Discussion Board feature is one that is not readily found on the WebCT interface. As it does not appear on the sidebar of the subject's homepage, a number of steps are required to locate it. This may partially explain the very low level of activity from both the High Distinction and N2 students. Despite being shown all the key features of WebCT at the commencement of the semester, it is possible that many students were not aware that this feature existed, or perhaps if they were aware, it was not considered an effective means of communication with this low level of interaction. Similar issues were raised in Concannon, Flynn, and Campbell (2005) who questioned whether technologically-enhanced learning systems were flexible enough to meet the design requirements of an effective learning system. This is reinforced by Osgerby (2013) who comments on the reliability and technical quality of the learning management system, such as WebCT. These factors have been found to have an impact on students' attitudes and willingness to engage with online learning resources.

Details accessed from the WebCT Course Management Statistical Tools for Semester 2/2011 indicated the reading of discussion board messages averaged approximately four messages and one message respectively. There was, however, a greater contrast by comparing the student achieving the highest mark of 96 in this subject reading 21 messages compared to the student with the lowest mark of eight who did not read any messages over the 12 week semester. This student's poor performance due to missed assessments may have been attributed to this lack of awareness and interaction.

These findings highlight a possible relationship between the level of student engagement with online resources and their overall academic result. Across the online activities measured, namely the number of sessions logged, online assessments attempted, files viewed and messages read on the discussion board, the time spent on each activity was considerably longer for the High Distinction students. These results seem to be consistent with prior research which suggests that the online provision of course materials can have a positive impact on students' examination performance as reported by Perera and Richardson (2010).

\section{Evaluation of Subject Website}

In Semester 2/2011, the final semester under review, the quality of the subject website and the usefulness of its main features was measured using a 4 point rating scale with $1=$ low, $2=$ medium, $3=$ high and $4=$ very high, 'not applicable' was an option if students did not use the feature or did not perceive it to be useful. These results are shown in Table 6.

The most useful features were exam solutions (3.5) and lecture notes (3.4), closely followed by subject information, updates and announcements (3.3). Students also rated weekly online tests (3.2) and online recordings (3.1) as highly useful. These results are similar to previous research on the use of WebCT and its effect on student motivation which found that various design features of WebCT, such as the provision of lecture notes, use of bulletin board, online assessment significantly influenced the level of student satisfaction (de Lange, Suwardy, \& Mavondo, 2003).

The features which enable students to communicate with each other and with teaching staff rated amongst the lowest; discussion board (2.7) and e-mentoring (2.8) but still regarded as moderately useful in their learning in this subject. This is similar to an observation made in a study conducted by Halabi and de Lange (2011) that students feel reluctant to engage in two-way online activities.

Students expressed a high level of satisfaction with its content and design, rating the overall quality of the subject website 3.3 out of a maximum score of 4.0. 
Table 6 - To what extent were the following website features useful in your learning in this subject?

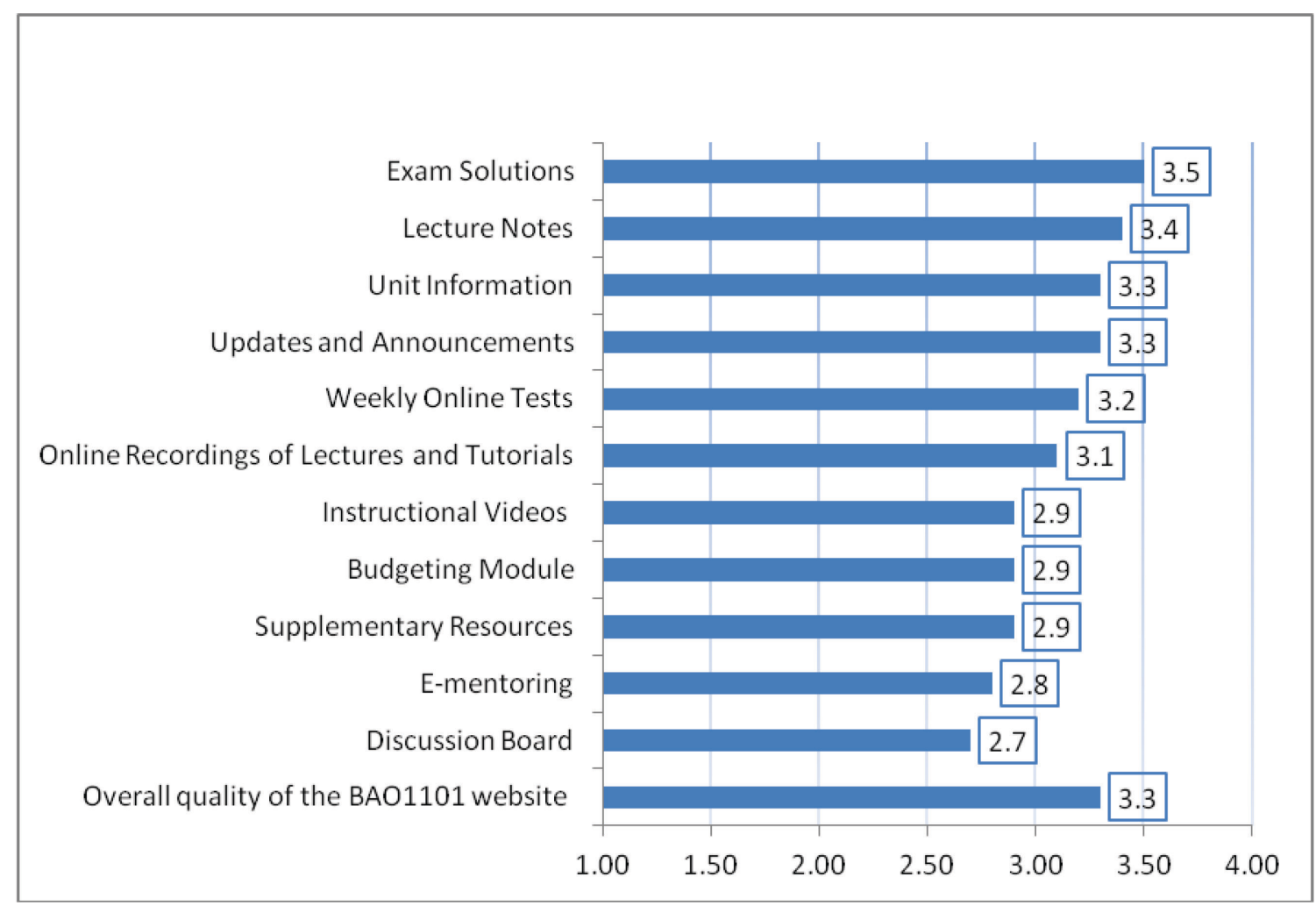

\section{Limitations}

It is acknowledged that there are various contributing factors other than the availability of additional online learning options that may influence the learning outcomes examined in this paper.

These results may have been affected by the relative quality of the resources available. There were some technical issues which compromised the audio and visual quality of the online recordings of lectures and tutorials. This may have impacted the students' responses to these options

Similarly, student views of traditional classrooms versus online learning resources may vary due the teaching provided in a face-to-face setting. Over the four semesters reviewed, there were on average, ten staff responsible for the teaching in this first-year accounting subject. Each of the staff differs in terms of his or her level of experience, teaching style and interpretation of the content. These factors may have also contributed the students' perception of their learning experience. Despite these limitations, the findings provide a starting point for further statistical analysis and future research.

\section{Future Research}

For possible future research, qualitative data collected from the student surveys conducted from Semester 1/2010 through to Semester 2/2011 but not included in this current paper can be used to identify the features recommended by students to further improve the quality of the subject website. It was of interest to find that the three new online options (recorded lectures, recorded tutorials, and an online tutorial) did not rate in the top five website features ranked by students as useful in their learning of this subject. The most useful features were Exam Solutions, Lecture Notes and Subject/Unit Information. If students perceived these basic needs as the most beneficial to 
their learning, it poses the question ... as academics do we need to re-evaluate what we spend our time on in creating appropriate online support?

\section{Conclusion}

The results of this research indicate that despite having three new online options readily available via WebCT, there was still strong support for the traditional face-to-face approaches delivery as more effective learning options. From Semester 1/2010 through to Semester 2/2011, students ranked face-to-face lectures as the most effective learning option, closely followed by face-toface tutorials. Of the online options, the viewing of recorded lectures rated the best. Although there was a continual increase in the mean score over the four semester period, it rated well below the face-to-face options.

To determine whether the online access to recorded lectures and tutorials had any impact in assisting the students' learning in this subject and potentially affecting their assessment outcomes, a review was conducted to compare the overall pass rates attained in this subject prior to WebCT and after the implementation of WebCT. Greer (2001) and Nicol (2006) suggest that change to assessment and innovative use of computer-based assessment may positively impact on learning.

It was found that the improvement was most significant from 2009 to Semester 1/2010 where the overall pass rate increased from $70 \%$ to $80 \%$ which coincided with the availability of online recordings lectures and tutorials. In Semester 1/2011, the overall pass rate peaked at $82 \%$ the highest attained in this first-year introductory accounting subject. By Semester 2/2011, this had dropped back to $72 \%$. It was acknowledged that there is the possible interplay of different factors impacting on the overall pass rate. Longer working hours, larger proportions of non-accounting students with no previous accounting studies, low attendance rates and the quality of teaching were identified as factors which may adversely affect the overall pass rate.

An investigation of WebCT Course Management Statistical Tools revealed a positive relationship between the level of student engagement with online resources and their overall academic result. Across the key online activities measured, namely the number of sessions logged, online assessments attempted, files viewed and messages read on the discussion board, the time spent on each activity was considerably longer for the High Distinction students in comparison to failed students. It may be expected that there would be a correlation between the amount of time that students spent on their studies offline which would also affect these learning outcomes. Perhaps the effectiveness and attractiveness of online learning resources may be improved by increasing student interaction immediately after use of the online resource.

With the rapidly changing nature of accounting education, Rebele (2002) highlighted the importance of research specific to the effective use of technology in accounting education. In a review of more recent literature by Apostolou et al. (2011), the need for further research in this area is still relevant. By addressing some of the issues relating to student engagement with online resources and its impact on learning outcomes, these findings aim to contribute to this current gap in research.

\section{Acknowledgements}

Thank you to the reviewers for their invaluable feedback and recommendations which have been incorporated into this submission.

\section{References}

Apostolou, B., Hassell, J. M., Rebele, J., \& Watson, S. F. (2011). Accounting education literature review (2006-2009). Journal of Accounting Education, 28(3-4), 145-197. doi: 10.1016/j.jaccedu.2011.08.001 
Bates, A. W., \& Poole, G. (2003). Effective teaching with technology in higher education. Foundations for success San Francisco, USA: Jossey-Bass.

Biggs, J. (2003). Teaching for quality learning at university (2nd ed.). Maidenhead: Open University Press.

Bonk, C. J., \& Graham, C. R. (2006). The handbook of blended learning - Global perspectives, local designs. San Francisco, CA, USA: Pfeiffer - An Imprint of Wiley.

Buzzetto-More, N. A. (2008). Student perceptions of various e-learning components, Interdisciplinary Journal of E-Learning and Learning Objects, 4, 113-135. Available at http://www.ijello.org/Volume4/IJELLOv4p113-135Buzzetto413.pdf

Concannon, F., Flynn, F., \& Campbell, M. (2005). What campus based students think about the quality and benefits of e-learning. British Journal of Educational Technology, 36(3), 501-512.

Davies, J., \& Graff, M. (2005). Performance in eLearning: Online participation and student grades. British Journal of Education Technology, 36(4), 657-663.

de Lange, P., Suwardy, T., \& Mavondo, F. (2003). Integrating a virtual learning environment into an introductory accounting course: Determinants of student motivation. Accounting Education, 12(1) 1-14.

Entwistle, N., McCune,V., \& Hounsell, J. (2002). Approaches to study and perceptions of university teaching-learning environments: Concepts, measures and preliminary findings. Available on-line at www.ed.ac.uk/etl/docs/ETLreport1.pdf

Entwistle, N., \& Ramsden, P. (1983). Understanding student learning. London: Croom Helm.

Halabi, A. K., \& De Lange, P. (2011). The usefulness and interactions of WebCT from an accounting student's perspective. Advances in Accounting Education, 12, 77-95.

Halabi, A. K., Tuovinen, J. E., \& Farley, A. A. (2005). Empirical evidence on the relative efficiency worked examples versus problem-solving exercises in accounting principles instruction. Issues in Accounting Education, 20(1), 21-32.

Ginns, P., \& Ellis, R. (2007). Quality in blended learning: Exploring the relationships between on-line and face-to-face teaching and learning. Internet \& Higher Education, 10(1), 53-64.

Greer, L. (2001). Does the method of assessment of a module improve the performance of a student? Assessment and Evaluation in Higher Education, 26(2), 127-138.

Naaj, M. A., Nachouki, M., \& Ankit, A. (2012). Evaluating student satisfaction with blended learning in a gender-segregated environment. Journal of Information Technology Education: Research, 11, 185200. Available at http://www.jite.org/documents/Vol11/JITEv11p185-200AbouNaaj0979.pdf

Nelson, K., Kift, S., Humphreys, J., \& Harper, W. (2006). A blueprint for enhanced transition: Taking an holistic approach to managing student transition into a large university. Proceedings First Year in Higher Education Conference, Gold Coast, Australia.

Nicol, D. (2006). Increasing success in first year courses: Assessment re-design, self-regulation and learning technologies. Proceedings of the 23rd Annual ASCILITE Conference: Who's learning? Whose technology? Sydney, Australia, 3-6 December, 2006, 589-598.

Osgerby, J. (2013). Students' perceptions of the introduction of a blended learning environment: An exploratory case study. Accounting Education, 22(1), 85-99.

Perera, L., \& Richardson, P. (2010). Students' use of online academic resources within a course web site and its relationship with their course performance: An exploratory study. Accounting Education, 19(6), 587-600.

Phillips, R., Gosper, M., McNeill, M., Woo, K., Preston, G., \& Green, D. (2007). Staff and student perspectives on web based lecture technologies: Insights into the great divide. ICT: Providing Choices for Learners and Learning. Proceedings ASCILITE Singapore 2007

Prosser, M., \& Trigwell, K. (1999). Understanding learning and teaching: The experience in higher education. Buckingham: Society for Research into Higher Education and Open University Press. 
Rebele, J. E. (2002). Accounting education's uncertain environments: descriptions and implications for accounting programmes and accounting education research. Accounting Education, 11(1), 3-25.

Sanders, D., \& Morrison-Shetlar, A. (2002). Student attitudes toward web-enhanced instruction in an introductory biology course. Journal of Research on Computing in Education, 33(3), 251-262.

Taplin, R. H., Low, L. H., \& Brown, A. M. (2011). Students' satisfaction and valuation of web-based lecture recording technologies. Australasian Journal of Educational Technology, 27(2), 175-191.

Wells, P., de Lange, P., \& Fieger, P. (2008). Integrating a virtual learning environment into a second-year accounting course: Determinants of overall student perception. Accounting \& Finance, 48(3) 503-518.

Williams, A., Birch, E., \& Hancock, P. (2012). The impact of online lecture recordings on student performance. Australasian Journal of Educational Technology, 28(2), 199-213.

von Konsky, B. R., Ivins, J., \& Gribble, S. J. (2009). Lecture attendance and web based lecture technologies: A comparison of student perceptions and usage patterns. Australasian Journal of Educational Technology, 25(4), 581-595

\section{Biography}

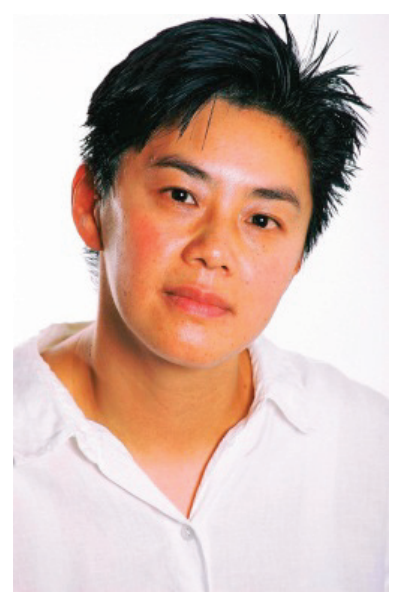

Lily Wong is the Unit Coordinator for Introductory Accounting, one of the largest student cohorts at Victoria University. Since undertaking her $\mathrm{PhD}$, she has been actively involved in the research, development and integration of online teaching resources to improve the student learning experience for first year accounting students. Lily's contribution to teaching and learning has been formally recognised as a recipient of university and national awards. These include the Australian Awards for University Teaching in which she was a finalist; an Australian Learning and Teaching Council Citation for Outstanding Contribution to Student Learning; and recipient of the Vice-Chancellor's Peak Award for Excellence in Teaching and Learning. 